\title{
LEGAL BIOGRAPHY
}

\section{Guest Editorial: Legal Biography}

Biography has always been a very popular subject for academic study and publication. The lives of great men and women from history and from contemporary life continue to fascinate and intrigue us, and their autobiographies and biographies often provide valuable insights into historical events and movements as well as shining a light onto their personal motivations and preoccupations. As David Sugarman explains in his keynote special issue article on alternative visions of legal biography, legal biographies have had something of a renaissance recently with a number of legal biographies being published on such diverse legal figures as Kahn-Freud, Hughes Parry and Gwyneth Bebb as well as exciting new institutional initiatives being established such as the Eminent Scholars Archive at the University of Cambridge' and the LSE Legal Biography Project. ${ }^{2} \mathrm{He}$ argues persuasively that we may be witnessing a turning point in legal scholarship at the moment with the strong possibility that legal biography writing will become an increasingly important area for legal research in the future.

This interesting idea of a turning point in legal scholarship, the methodological considerations and problems involved in doing archival research for legal biographies and the ongoing difficulties for scholars in identifying the key sources for legal biography research, were the three main reasons why a national socio-legal training day on legal biography was organised by the Institute of Advanced Legal Studies, the British Library and the Socio-Legal Studies Association and held at IALS in May 2013. Jon Sims, Curator for law and socio-legal studies at the British Library, Professor Linda Mulcahy at the LSE and the SLSA and myself were keen to provide a national forum for interested academics to discuss the recent renaissance in legal biography research and for methodological issues to be raised and discussed. We also wanted expert librarians and archivists to highlight the usefulness of their rich and diverse collections for legal biography research. The national sociolegal training day proved to be very popular and successful with much discussion between the speakers and the attendees throughout the programme. The articles included in this special issue of Legal Information Management derive from the inspiring presentations during that day.

\section{LEGAL BIOGRAPHY RESEARCH - METHODOLOGICAL ISSUES}

As well as David Sugarman's keynote article which summarises the current position of legal biography in legal scholarship, several other academics have written brief articles on the methodological considerations and problems of archival research for legal biographies. Rosemary Auchmuty from Reading University discusses how she diligently researched the life story of Gwyneth Bebb (the woman at the heart of the seminal Bebb $v$ The Law Society case which concerned women's admission to the legal profession) who sadly left so little trace of her life in historical records. Linda Mulcahy at LSE and Les Moran at Birkbeck both write on different legal biographical topics, but both show so well how paying closer attention to historical paintings and judicial portraits can assist legal biographers with their research. Finally in researching the British Constitutionalist Sir Ivor Jennings (1903-1965), Mara Malagodi at LSE highlights why the collection of his private papers held at the Institute of Commonwealth Studies in London has been so under-researched.

\section{LEGAL BIOGRAPHY RESEARCH - LIBRARY AND ARCHIVE SOURCES}

The brief articles by academics on methodological issues, are followed by a number of longer articles by librarians and archivists highlighting how the collections of important research libraries and archive sources can be so useful for legal biography research. Jon Sims writes so well on the huge and diverse collections at the British Library, Elizabeth Dawson summarises the interesting and unique archival sources for legal biography at IALS Library, whilst Susannah Rayner introduces the rich and surprising archival collections held at SOAS Library. Lesley Dingle's article is a fascinating description of the setting up and development of the wonderful Eminent Scholars Archive at the Squire Law Library in the University of Cambridge. This unique digital archive provides rare insights into the careers of legal scholars, jurists and practitioners with connections to Cambridge. Finally Guy Holborn, Librarian at Lincoln's Inn and adviser to the LSE Legal Biography Project, discusses how the rich archives at the Inns of Court can assist legal biographers with their research in so many diverse ways.

\section{CONCLUSIONS}

It is hoped that these special issue articles will help us to understand more the varied methodological concerns and problems of legal biography researchers, as well as helping to highlight the many research libraries and specialist archives which can provide expert assistance with legal biography research.

Finally I can report that the national training day on legal biography has already contributed to the debate in academic circles on the apparent renaissance in legal biography research. Linda Mulcahy and David Sugarman have since gone on to co-edit a series of articles on legal biography (written mostly by the authors contained in this Legal Information Management issue) which will be published in a special issue of the Journal of Law and Society in 2015. They kindly acknowledge their debt to the joint IALS, British Library, Socio-Legal Studies Association national training day in their official proposal. This is an unexpected, but very pleasing additional outcome of a stimulating day in May 2013.

David Gee Deputy Librarian Institute of Advanced Legal Studies University of London 


\title{
Footnotes
}

' Eminent Scholars Archive: http://www.squire.law.cam.ac.uk/eminent_scholars/

${ }^{2}$ LSE Legal Biography Project: http://www.lse.ac.uk/collections/law/projects/legalbiog/lbp.htm

\section{Alternative Visions of Legal Biography: an Abstract}

\author{
Abstract: David Sugarman reflects briefly on developments regarding legal biography \\ and considers the future role and value of biography within the legal community and \\ especially in the context of socio-legal research. \\ Keywords: biography; legal biography
}

Biography is booming. Shakespeare, Pepys, Jane Austen and Steve Jobs for example, have all been the subject of recent biographies that have sold millions, as have celebrity biographies and autobiographies.

While political biographies are not in the same league sales-wise, they remain popular'. Artists, philosophers, historians and even economists, from Bagehot and Beveridge to Warhol and Wittgenstein, have all attracted a steady stream of high quality biographies.

At first blush, the contrast with legal biography in Britain is striking. The once popular biographies of illustrious lawyers and judges, typified by Marjoribanks' biography of Marshall Hall ${ }^{2}$ and Lewis' biographies of Lords Atkin and Hailsham ${ }^{3}$, appear to be in decline. Apparently they are selling less, and certainly fewer are published today than in the previous two hundred years. Perhaps contemporary lawyers and judges are less colourful, lack the popular notoriety and have become more narrowly professional than their counterparts of yore? Perhaps they have been eclipsed by a different notion of "celebrity", publication and the media?

One could also point to the invidious comparison between the quantity and quality of legal biography in, say, contemporary Canada and the USA relative to Britain. While the best of legal life writing harnesses historical empathy with a commitment to the careful and conscious scrutiny of the past, the worst tends towards hagiography.

However, change is in the air. High-quality British academic legal biography, pioneered by Heuston and Stevens in the 1960's and '70's, has grown and established a small, marginal, but discernible niche in the world of scholarship, albeit, a precarious one ${ }^{4}$. Work illustrative of this biographical turn includes Auchmuty on Gwyneth Bebb, Beatson and Zimmermann on German-speaking émigré lawyers in twentieth century Britain, Dukes on KahnFreund, Duxbury on Pollock, Lacey on Hart, Parry on Hughes Parry and Prest on Blackstone ${ }^{5}$. Institutional initiatives at LSE$^{6}$ and Cambridge ${ }^{7}$ also indicate that a struggle is under way to sustain legal biography in Britain as never before. Thus, we may be witnessing a turning point, although only time will tell.

To date, the bulk of legal biographies have focused on the lives of the elite; most often white, male judges ${ }^{8}$. Court officials, women" and other "outsiders", litigants, the diverse audiences of the law beyond the judiciary and lawyers, legal communications and legal objects ${ }^{10}$ have tended to receive short shrift. While the history of law firms has added considerably to our understanding of legal practice, and the inter-play between the public sphere and the private sphere in legal life "', the impact of these histories has been largely confined to the realm of business history. The approaches adopted, and the source material utilised, by legal biography tend to be less diverse than the best of contemporary life writing. Important sources - such as autobiography, obituaries and eulogies, advertisements, oral history ${ }^{12}$, visual mater$\mathrm{ial}^{13}$ and objects - are frequently neglected ${ }^{14}$. The physical and sensory textures of everyday legal life ${ }^{15}$ receive scant attention. Consequently, legal biography has been largely cut-off from, and seen as irrelevant to, intellectual, 